\title{
CONFLICTING CLAIMS TO OIL AND NATURAL GAS RESOURCES OFF THE EASTERN COAST OF CANADA
}

\section{COLIN DOUGLAS*}

\begin{abstract}
The province of Newfoundland and the federal government both claim ownership of the oil and gas resources off the coast of Newfoundland. This paper examines the legal arguments that could be raised in the event that the issue is litigated. Matters examined include the applicability of the continental shelf doctrine, whether Newfoundland could successfully assert a more limited claim to the area within three miles of its shoreline, and the possible legislative competence of each government in relation to the offshore oil industry.
\end{abstract}

\section{INTRODUCTION}

The Province of Newfoundland claims that it, and not the Federal Government, exclusively owns the mineral resources under the waters off its eastern coast. The Federal Government was the successful party when the issue of ownership of oil off the west coast of Canada was settled in the British Columbia Offshore Minerals Reference. ${ }^{1}$ Nevertheless, Newfoundland has distinguished its claim from that of British Columbia. The claim of New foundland must stand or fall on its own merits. It is quite possible that a political settlement may be arrived at by the two governments. Nevertheless, it is important to examine the nature of the legal claims which each government can make.

\section{THE CLAIMS OF THE TWO GOVERNMENTS}

\section{A. Claim One}

The most important claim made by each of the two governments is exclusive entitlement to the resources under the continental shelf adjacent to Newfoundland. Newfoundland claims that at the time of union with Canada (on midnight, March 31st, 1949) these resources belonged to Newfoundland, and thus by the terms of union still belong to Newfoundland. ${ }^{2}$ This claim is based on the assertion that by 1949 a coastal state had by customary international law the exclusive right to exploit the resources under the continental shelf adjacent to its landmass. Canada claims that this right was not recognized at international law until after Newfoundland had become a province. Thus when these rights accrued they accrued to Canada as the coastal sovereign state.

Discussion of this claim will begin with a description of the continental shelf as a physical feature of the earth. Particular emphasis will be placed on the continental shelf and the resources under it in the vicinity of Newfoundland.

- Articling Student, Hughes, Amys, Toronto, Ontario, and recipient of the Foundation's 1978 Student A ward.

1. In the Matter of a Reference by The Governor General in Council Concerning the Ownership of and Jurisdiction Over Offshore Mineral Rights as set out in Order in Council P.C. 1965-750 Dated A pril 26 1965[1967] S.C.R.792 [hereinafter referrd to as the "B.C. Offshore Minerals Reference".].

2. Department of Mines and Energy, Government of Newfoundland. Heritage of the Sea. . our case on offshore mineral rights 2. 
The continental shelf doctrine, a doctrine of international law which was at least originally based on the physical continental shelf, will be discussed next. Put simply, this is the doctrine that a coastal state has the exclusive right to exploit the minerals under the continental shelf adjacent to its landmass. The requirements which must be met before a new principle of international law can be said to have come into existence will be examined. In drawing a conclusion as to when the continental shelf doctrine became a customary rule of international law two sources of evidence will be considered. First, the proclamations of states and the actions of states and oil companies will be studied from 1936 through 1964 . Second, judicial decisions and the opinions of some writers will be examined.

\section{B. Claim Two}

Even if Newfoundland could not establish the first claim it might succeed on a less extensive second claim. Newfoundland could claim that at the time of union it was entitled at international law to exercise sovereignty within 3 miles of its shoreline, and that it did so. Thus before union this area would have been part of Newfoundland and the minerals in it would have belonged to Newfoundland. By the terms of union this area and the minerals in it would continue to belong to Newfoundland.

Canada may deny that Newfoundland was entitled to sovereignty over this 3 mile strip before union. It might be claimed that sovereignty was first exercised over this 3 mile belt by Canada.

Discussion of this claim will begin with an effort to determine the period during which New foundland was a sovereign state. Following this, the effect of the union of Newfoundland with Canada will be discussed. The leading case in the area, the B.C. Offshore Minerals Reference ${ }^{3}$, will then be discussed. Finally, there will be a conclusion as to which government is entitled to the resources under the territorial waters surrounding Newfoundland.

\section{Claim Three}

Both governments will claim the widest possible legislative competence with regard to the offshore oil industry. Because a specific fact situation is lacking and the scope of this essay is limited, only a brief discussion of this claim will be undertaken.

\section{CLAIM ONE}

\section{A. The Continental Shelf as a Physical Feature}

The term "Continental Shelf" was first used by a geographer in 1898. In 1967 a U.N. Committee defined a number of the terms which are used in discussions of the shelf." These definitions accord well with those of geographers and were developed for use in discussion of geography, not law. Familiarity with them will give the reader a good understanding of the shelf as a physical feature. ${ }^{5}$

3. B.C. Offshore Minerals Reference, supra, n. 1.

4. The definitions were developed by the Economic and Technical Working Group of the United Nations ad hoc Committee on the Peaceful Uses of the Seabed and Ocean Floor which was established by the U.N. General Assembly in 1967.

5. United Nations Report of the ad hoc Committee to Study the Peaceful Uses of the Seabed and the Ocean Floor beyond the Limits of National Jurisdiction U.N. Doc. A/7230 (1967)22-3. 
Continental Shelf: The area of the ocean floor between the mean low water line and that change in the inclination of the floor, from about one-eighth of one degree to more than three degrees, that marks the beginning of the continental slope which occurs at various depths, usually between 130 and 200 meters, but exceptionally as shallow as 50 meters or as deep as 500 meters. The width of the shelf ranges from less than one mile up to 800 miles. When the increase in slope is very gradual, the point of maximum rate of change of slope is considered to be the edge of the shelf.

Continental Slope: The area of the ocean floor extending from the outer edge of the continental shelf to the abyssal ocean floor, usually from 10 to 20 miles wide. The inclination of the slope varies widely from as little as three degrees to over forty-five degrees. Geologically it marks the rather abrupt transition from continental or sialic crust to oceanic or simatic crust.

Continental Rise: Apron of clastic sediments, wherever deep sea trenches are absent, that slopes gently oceanward from the base of the continental slope, usually in 2,000 to 5,000 meters of water.

Continental Margin: That region of the earth's crust where the continental sialic rocks are covered by the sea.

The continental margin, which is a natural underwater extension of the continents, consists of the shelf and the slope and a part of the rise. ${ }^{6}$

In the entire world the continental shelves comprise an area of 11 million square miles. ${ }^{7}$ In 1947 it was estimated that 1,000 billion barrels of oil were contained in the continental shelves of the world. ${ }^{8}$

Newfoundland claims that it is entitled to all of the resources in the adjacent continental margin and calls this the "legal continental shelf" or "the natural prolongation of (New foundland's) landmass". ${ }^{9}$ By the calculations of Newfoundland this margin ranges from 200 miles in width off Labrador to over 450 miles in width off St. John's and is under up to 10,000 feet of water.

In the area surrounding Newfoundland one geographer has chosen the 400 meter isobath as delimiting the edge of the continental shelf, the 2,500 meter isobath as delimiting the edge of the continental slope, and the 3,500 meter isobath as delimiting the base of the continental rise. ${ }^{10}$ An earlier geographer chose the 500 meter isobath as the edge of the continental shelf in this area. ${ }^{11}$

For the disputed area estimates have been made of the quantity of hydrocarbons which could be discovered, produced and sold on a commercially profitable basis. It is believed that there is a $50 \%$ likelihood that the quantity is 40 trillion cubic feet of gas and 3.5 billion barrels of oil..$^{12}$

The area in dispute is one of the most hazardous offshore drilling areas in the world. Winds have been recorded at a sustained hourly rate of 85 m.p.h. near St. John's and 125 m.p.h. near the northern tip of Labrador. ${ }^{13}$ Ice is a very serious problem. Approximately 400 icebergs per year drift as far south as St. John's at an average speed of 6 to 10 miles per day. ${ }^{14}$

6. A. Gotlieb, "Recent Developments Concerning the Exploration and Exploitation of the Ocean Floor" (1969) 15 McG.L.J. 260 at 265.

7. Z. Slouka, International Custom and the Continental Shelf(1968)41.

8. Id. at 42.

9. Department of Mines and Energy, Government of Newfoundland, supra, n. 2 at 2.

10. A. Grant, "The Continental Margin Off Labrador and Eastern Newfoundland-Morphology and Geology" (1972)2 Cdn. J. Earth Sc. 1394 at 1418.

11. O. Krummel, "Handbuch der Ozeanographic," Band I (1907) 105 in N. Mouton, The Continental Shelf (1952) 14.

12. Department of Mines and Energy, Government of Newfoundland The Province of Newfoundland and Labrador Offshore Petroleum Resources Review (unpublished, 1976) 17.

13. Id at 2.

14. Id at 4 . 


\section{B. The Requirements for the Existence of a Customary Rule of International Law}

How can the time at which the continental shelf doctrine became a customary rule of international law be determined? The following are the traditional requirements for the coming into existence of a new customary rule of international law: $:^{15}$

(a) concordant practice by a number of states with reference to a type of situation falling within the domain of international relations

(b) continuation or repetition of the practice over a considerable period of time

(c) conception that the practice is required by, or consistent with, prevailing international law; and

(d) general acquiescence in the practice by other States.

In measuring the extent of the concordant practice the appropriate measure is not the number of states which observe that practice but rather it is the number of state to state relationships in which that practice is observed. ${ }^{16}$ It is generally accepted that the stature and influence of the states which maintain the practice must be considered together with the mere absolute number of them.

It is generally admitted that it is impossible to fix any specific length of time necessary for the emergence of a customary rule of international law. ${ }^{17}$ The length of the period of time involved is of less significance than the number and importance of the events which transpire within it. ${ }^{18}$

Merely demonstrating the existence of a course of state practice will not conclusively prove the existence of a customary rule of international law. ${ }^{19}$ Such a demonstration will really only prove that events were consistent with the existence of a customary rule. Much more convincing is a demonstration that the practice was engaged in by the states because each was conscious of a legal duty to maintain that practice.

\section{Proclamations and Actions of States and Oil Companies}

For a long period, the bed and the surface of the high seas were at international law incapable of occupation by any state. ${ }^{20}$ Nevertheless, the subsoil under the bed of the high seas was considered capable of types of occupation which did not obstruct communication and trade. ${ }^{21}$ Until the Second World War the subsoil under the bed of the high seas was exploited almost solely by means of shafts driven under it from coal mines on shore. This exploitation caused no international controversy.

The first legal act whereby rights of a territorial nature were claimed over zones under the high seas occurred in $1942 .^{22}$ The Treaty Relating to the Submarine Areas of the Gulf of Paria Between Venezuela and the United Kingdom, February 26, 1942 was signed. ${ }^{23}$ Later in the year the parties annexed the submarine areas on which they had agreed by

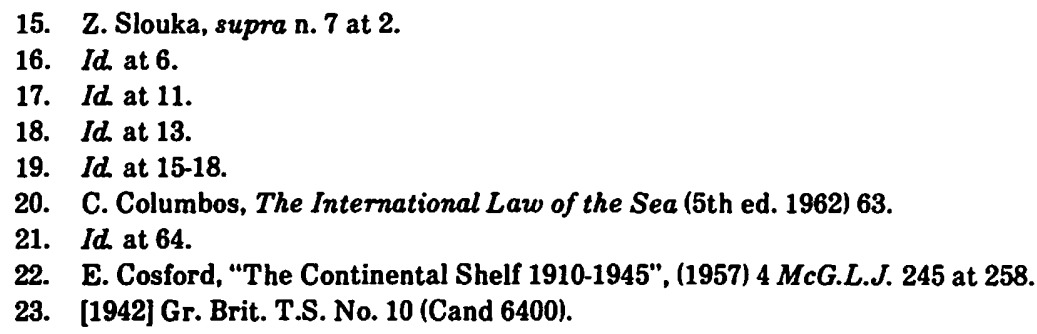

15. Z. Slouka, supra n. 7 at 2.

16. Id. at 6 .

17. Id at 11.

18. Id. at 13.

19. Id at 15-18.

20. C. Columbos, The International Law of the Sea (5th ed. 1962) 63.

21. Id. at 64.

22. E. Cosford, "The Continental Shelf 1910-1945", (1957) 4 McG.L.J. 245 at 258.

23. [1942] Gr. Brit. T.S. No. 10 (Cand 6400). 
separate national unilateral instruments. ${ }^{24}$ Venezuela was first approached by Britain in 1936 with the aim of concluding this treaty. ${ }^{25}$

The parties gave no legal justification for their actions and the continental shelf was not mentioned. ${ }^{26}$ In the British annexation the areas annexed were described as "the submarine areas of the Gulf of Paria" and "the sea bed and subsoil situated beneath the waters, excluding territorial waters". ${ }^{27}$ Use of the term "shall be annexed to and form part of His Majesty's dominions" implied that a right to territorial sovereignty was asserted. ${ }^{28}$ The Gulf is isolated from general high seas navigation and was almost entirely enclosed by British and Venezuelan territory. ${ }^{29}$ Nevertheless, the high seas status of the waters and the airspace above was expressly preserved. ${ }^{30}$ At least one writer does not believe that the British practice regarding the Gulf of Paria significantly affected the legal status of the continental shelf in general. ${ }^{31}$

In 1944 Argentina decreed that pending the enactment of special legislation "the zones of the epicontinental sea of Argentina, shall be deemed to be temporary zones of mineral reserves. ..." ${ }_{32}$

On September 28, 1945 President Truman made a proclamation for the United States which read in part: ${ }^{33}$

\begin{abstract}
Whereas it is the view of the Government of the United States that the exercise of jurisdiction over the natural resources of the subsoil and seabed of the continental shelf by the contiguous nation is reasonable and just, since the effectiveness of measures to utilize or conserve these resources would be contingent upon cooperation and protection from the shore, since the continental shelf may be regarded as an extension of the landmass of the coastal nation and thus naturally appurtenant to it, since these resources frequently form a seaward extension of a pool or deposit ly. ing within the territory, and since self protection compels the coastal nation to keep close watch over activities off its shores which are of the nature necessary for utilization of these resources;
\end{abstract}

the Government of the United States regards the natural resources of the subsoil and seabed of the continental shelf beneath the high seas but contiguous to the coasts of the United States as appertaining to the United States, subject to its jurisdiction and control.

It is noteworthy that this proclamation claimed only jurisdiction over the resources of the physical continental shelf. The proclamation contains reasons justifying the making of the claim. It facilitated, and indeed seems to have invited, the making of such claims by other nations. It has been argued that this claim and claims made by Britain to the Gulf of Paria demonstrate that by 1945 the two great maritime nations (Britain and the United States) recognized and supported the continental shelf doctrine. This contention will not be explored since this essay is concerned only with whether the continental shelf doctrine was a customary rule of international doctrine law in 1949.

24. E. Cosford, supra n.22 at 259.

25. Id at 258.

26. Id. at 239.

27. Id. at 261.

28. Id.

29. Id at 259 fn. 41.

30. Id. at 263.

31. Z. Slouka, supra n.7 at 74.

32. N. Mouton, The Continental Shelf (1952) 14.

33. Presidential Proclamation 2667, September 28, 1945 With Respect to Natural Resources of the Subsoil and Seabed of the Continental Shelf (1945) 10 Fed. Reg. 12303 in B.C. Offshore Minerals Reference, supra n.1, s.818, sub. 83. 
A complex series of proclamations and decrees and technical developments followed the Truman Proclamation. If the dispute between the Federal Government and New foundland were to come to trial the task of setting out these developments in detail and assessing their significance would be monumental. Nevertheless, the essentials of these developments, as derived from several sources, can be set out: ${ }^{34}$

1945: Mexico, by presidential declaration, claims all the resources within its continental shelf as delimited by the 200 meter isobath.

1946: Two exploration crews are active on the U.S. Continental Shelf in the Gulf of Mexico (hereafter termed the U.S. Gulf shelf). Panama states in its constitution that the submarine continental shelf which appertains to the national territory belongs to the state. Chile (by Presidential declaration) and Peru (by Presidential decree) each claim sovereignty over the adjacent continental shelf and entitlement to its resources.

1947: For the first time a well is completed beyond the 3 mile limit (11 miles offshore in $17 \mathrm{ft}$. of water on the U.S. Gulf shelf). ${ }^{35}$

1948: On the U.S. Gulf shelf 20 oil companies have 30 exploration crews active and the total of wells now drilled stands at 26. By separate Orders in Council, Britain extends the boundaries of the Bahamas and Jamaica to include the submerged area of the continental shelf contiguous to the coasts of each colony.

1949: On the U.S. Gulf shelf 40 oil companies are exploring. The total of oil and gas wells drilled here is 53 and 20 are completed and producing. In November, Costa Rica, by decree, clarifies a claim (first made, by decree, in 1948) to sovereignty over the shelf and entitlement to its resources. Costa Rica also claims complete sovereignty over the shelf in a political constitution. At midnight, March 31st, Newfoundland enters confederation. In June the Philipines, by a somewhat ambiguous act, appears to claim entitlement to the resources of the adjacent shelf. Jurisdiction and sovereignty over the resources in contiguous shallow water is claimed by Iran in May and by proclamations in June by Bahrin, Abu Dhabi, Ajmon, Dubai, Kuwait, Qatar, Ras Al Kaimah, Sharjh and Umm Al Qaiwain.

1950: On the U.S. Gulf shelf a total of 120 oil and gas wells have been drilled and 60 are complete and producing. Shelf claims having the general characteristics of those discussed above are made by Pakistan, El Salvador, Ecuador and Brazil. The total number of governments which have made shelf claims now stands at 18.

1951: The United Kingdom transmits a formal objection to Honduras on A pril 23rd. It reads in part:.36

The action of the Government of Honduras, moreover, in claiming that sovereignty may be ex tended to a distance of 12 kilometres from the coast of the republic or alternatively over large and undefined areas of the high seas above the continental shelf, appears to be irreconcilable with the principles of international law governing the extent of territorial waters formerly recognized by the Government of Honduras and by the great majority of other maritime States.... His

34. The sources used were N. Mouton, supra n.32 at 253-60, and Z. Slouka, supra n.7 at 44,52, $54,55,56$. There were slight differences in the proclamations listed in the two sources and some of the proclamations made were somewhat ambiguous. Only a brief description of the more important proclamations is given in the text.

35. Z. Slouka, supra n.7 at 48 , fn.25.

36. N. Mouton, supra n.32 at 92. 
Majesty's Government ... [does] not recognize the claim of Honduras to exercise sovereignty over waters, outside a limit of 3 miles measured from the low water mark along the coast.

Both the United States and the United Kingdom make objections to certain other proclamations in which an excessively large area was claimed or total sovereignty, to the exclusion of rights usually associated with the high seas, was claimed. Such objections were also made in 1948 and 1950. Test drilling for oil on the continental shelf in the Persian Gulf begins.

1952: Shelf claims containing the general elements of those discussed above are made by the Republic of Korea, the Dominican Republic and Israel.

1953: Australia makes a claim to the shelf.

1955: India and Cuba each make a claim to the shelf. Oil test-drilling on the shelf off Guiana begins.

1956: Portugal makes a claim to the shelf. Oil test-drilling on the shelf off Argentina begins.

195\%: Oil test-drilling begins on the shelves off Nicaragua and Nigeria. The great majority of drilling rigs around the world are working in water 10 to 50 feet deep. ${ }^{37}$ The greatest depth of water in which drilling equipment is capable of operating is 180 feet (although this capability is not being used). ${ }^{38}$

1958: The Geneva Convention on the Continental Shelf is held. The Convention did not come into force, however, until the summer of 1964 when it had been ratified or acceded to by the required number of states. ${ }^{39}$ The following articles of the Convention are relevant to this discussion: ${ }^{40}$

Article 1. For the purpose of these articles, the term "continental shelr" is used as referring (a) to the seabed and subsoil of the submarine areas adjacent to the coast but outside the area of the territorial sea, to a depth of 200 meters or, beyond that limit, to where the depth of the superjacent waters admits of the exploitation of the natural resources of the said areas; (b) to the seabed and subsoil of similar areas adjacent to the coasts of islands.

Article 2.1. The coastal State exercises over the continental shelf sovereign rights for the purpose of exploring it and exploiting its natural resources.

2. The rights referred to in paragraph 1 of this article are exclusive in the sense that if the coastal State does not explore the continental shelf or exploit its natural resources, no one may undertake these activities, or make a claim to the continental shelf, without the express consent of the coastal State.

3. The rights of the coastal State over the continental shelf do not depend on occupation, effective or national, or on any express proclamation.

4. The natural resources referred to in these articles consist of the mineral and other non-living resources of the seabed and subsoil together with living organisms belonging to sedentary species, that is to say, organisms which, at the harvestable stage, either are immobile on or under the seabed or are unable to move except in constant physical contact with the seabed or subsoil.

Article 3. The rights of the coastal State over the continental shelf do not affect the legal status of the superjacent waters as high seas, or that of the air space above those waters.

Whether the Convention was merely declaratory of a customary rule of international law or was constitutive of a new rule is unclear. Fifty-five delegations participated in the debates of Committee Four (the Continental Shelf Committee) of the 1958 Geneva Conference. Of those 55, 20

37. Z. Slouka, supra n.7 at 68.

38. Id at 67.

39. Id at 90 .

40. United Nations, United Nation's Conference on the Law of the Sea U.N. Doc. A/CONF. $13 / \mathrm{L} .55$ (1958) in Z. Slouka, supra n.7 at 89. 
delegations asserted that the essentials of the continental shelf doctrine were at that time a customary rule of international law, 12 delegations denied that the doctrine was a customary rule and 23 delegations stated no opinion."1

There is no known case throughout the 1945 to 1958 period in which nationally controlled activity on the shelf left the geographical limits of the shelf. ${ }^{42}$

\section{Relevant Judicial Decisions and the Opinions of Some Writers}

A number of judgements relate directly to the issue of when the continental shelf doctrine became a customary rule of international law.

In the $A b u$ Dhabi Arbitration Lord Asquith discussed the state of international law regarding the continental shelf. ${ }^{43}$ While the result of this arbitration was binding on the parties, it is only the outcome of a private proceeding and not an authoritative pronouncement in the field of public international law." Lord Asquith engaged in a thorough discussion of whether at the time of an agreement made with an oil company the Sheikh of $\mathrm{Abu}$ Dhabi owned, or as a result of a proclamation made in 1949 he acquired, the right to win oil from any submarine areas lying outside the territorial waters of $\mathrm{Abu}$ Dhabi. Lord Asquith pointed out the very unsettled nature of the alleged doctrine. ${ }^{45}$ Some states claimed sovereignty while others claimed only control on jurisdiction. Some declarations purported to only declare an already existing right while others purported to constitute the right as a new right. The extent of the right was variously given as the edge of the shelf, the 200 meter isobath, 200 miles offshore, or a reasonable distance. At 256 Lord Asquith stated:

I am of opinion that there are in this field so many ragged ends and unfilled blanks, so much that is merely tentative and exploratory, that in no form can the doctrine claim as yet to have assumed hitherto the hard lineaments or the definitive status of an established rule of international law.

The decision of the International Court of Justice in the North Sea Continental Shelf cases has been cited as supporting the claim of Newfoundland. ${ }^{46}$ The Court said: $:^{47}$

More important is the fact that the doctrine of the just and equitable share appears to be wholly at variance with what the Court entertains no doubt is the most fundamental of all the rules of law relating to the continental shelf, enshrined in article 2 of the 1958 Geneva Convention though quite independent of it - namely that the rights of the coastal State in respect of the area of the continental shelf that constitutes a natural prolongation of its land territory into and under the sea exist ipso facto and $a b$ initio, by virtue of its sovereignty over the land, and as an extension of it in an exercise of sovereign rights for the purpose of exploring the seabed and exploiting its natural resources. In short, there is an inherent right. In order to exercise it no special legal process has to be gone through, nor have any special legal acts to be performed. Its existence can be declared (and many states have done this) but does not need to be constituted. Furthermore, the right does not depend on its being exercised. To echo the language of the Geneva Convention, it is "exclusive" in the sense that if the coastal state does not choose to explore or exploit the areas of the shelf appertaining to it, that is its own affair, but no one else may do so without its express consent.

41. Z. Slouka, supra n.7 at 91.

42. Id. at 69 .

43. Petroleum Development (Trucial Coast) Ltd. v. The Sheikh of Abu Dhabi (1952), Int. and Comp. L.Q. 247. [hereinafter referred to as $A$ bu Dhabi].

44. E. Cosford, "The Continental Shelf and the A bu Dhabi Award", (1952.55) 1 McG.L.J. 109 at 111.

45. Abu Dhabi supra n.43 at 255.

46. [1969] I.C.J. p. 22 Also in 1 C. Lay,New Directions in the Law of the Sea (1973) 134.

47. Id. para. 19. 
The tenability of this proposition was explored in New South Wales v. Australia. ${ }^{48}$ The case concerned a dispute between the Australian Federal government and the state governments over entitlement to offshore resources. McTiernan, J. remarked that the argument of the states was based on the proposition stated in the North Sea Continental Shelf Cases at par. $19 .^{49}$ In his opinion: ${ }^{50}$

To say the rights of coastal states in respect of the continental shelf existed from the beginning of time may or may not be correct as a matter of legal theory. In fact, however, the rights now recognized represent the response of international law to modern developments of science and technology, which permit the seabed to be exploited in a way which it was quite impossible for governments or lawyers of earlier centuries to foresee. In this matter the arguments of history are stronger than those of logic. In truth, when the Act was passed, the States had not asserted and did not have the rights to the continental shelf which the convention now accords to coastal States. Those rights, if theoretically inherent in the sovereignty of coastal States, were in fact the result of the operation of a new legal principle. When those rights were recognized by international law the Commonwealth was the international person entitled to assert them, and it did so. The assertion by the Commonwealth of those rights in no way interfered with any existing right of any State.

The opinions of writers on the question of when the continental shelf doctrine became a customary rule of international law vary. Slouka writes: ${ }^{51}$

By 1950 eighteen governments had made their continental shelf claims, at that time, however, only the United States and, to a lesser extent, the British sectors of the Gulf of Mexico shelf had an industrial development of a real consequence. Industrially, the continental shelf doctrine has been applied fully and generally only after 1950 .

No earlier than late December 1950 Hersht Lauterpacht (a respected authority) wrote that the continental shelf doctrine had "now, in any case, become part of international law by unequivocal positive acts of some states, ... and general acquiescence on the part of others"..$^{2}$ Although the essay is well argued it does not lend strong support to the claim of Newfoundland. If Professor Lauterpacht had believed that the continental shelf doctrine had become a customary rule of international law by 31 March 1949, 21 months before his essay was written, he would have said so. Indeed, many of the proclamations and events which Professor Lauterpacht incorporates in his arguments did not occur until after March 1949.

Another writer, Waldock, wrote in 1950 that he did not believe that the continental shelf doctrine was a customary rule of international law. ${ }^{53}$

It is submitted that the continental shelf doctrine was not a customary rule of international law when Newfoundland joined Canada at midnight, 31 March 1949. The traditional requirements for the coming into existence of a customary rule of international law were set out and discussed earlier. Although there may have been concordant proclamations and declarations by a significant number of states before March 1949, there could have been no concordant practice before this time. There were no

48. (1976) 8 A.L.R. 1 (Aust. S.C.).

49. Id. at 49 .

50. Id.

51. Z. Slouka, supra n.7 at 56.

52. H.Lauterpacht, "Sovereignty Over Submarine Areas", (1950) 27 Br. Yrbk. Int. L. 376. From Professor Lauterpacht's reference at 382 to a proclamation made on 21 December 1950 it is apparent that his essay must be taken as speaking no earlier than this date.

53. J. Hazard, "Newfoundland and the Continental Shelf: From Cod to Oil and Gas", (1976) 15 Col J. Trans. L. 138 at 150. 
complete wells beyond the 3 mile limit until 1947. By the end of 1949 there were 53 wells drilled and 20 producing on the U.S. Gulf shelf but many of these were within the 3 mile limit. Test drilling did not begin on any other shelf until 1951. In addition, it is questionable whether proclamations were concordant before March 1949. Even after this date claims to excessive areas and claims of complete sovereignty were being made and objected to. There is no real proof that any state, except possibly the U.S., refrained from exploiting the shelves of other states. Before 1949, and for some time after, the United States was the only state capable of exploiting the continental shelf outside of the three mile limit.

Even if the argument that the continental shelf doctrine was a customary rule of international law in March 1949 were to be accepted, two obstacles to the claim of Newfoundland would remain.

First, although in 1949 the term "continental shelf" was generally understood as referring only to the physical continental shelf (which at that time was generally thought of as under no more than 200 meters of water) Newfoundland claims the entire continental margin. This is composed of the continental shelf, the continental slope and a part of the continental rise. The continental margin claimed lies under as much as 10,000 feet of water. Newfoundland would have to either show that the continental margin was contemplated in the continental shelf doctrine of 1949 (a formidable task) or be content with entitlement only to the resources under the physical continental shelf. Second, even if the continental shelf doctrine was recognized at international law in 1949, the issue of whether Newfoundland was a sovereign state at that time still remains. Only if Newfoundland was then a sovereign state could it have been entitled to these resources.

In the years after World War One Newfoundland was moving slowly from the status of a British colony to that of a sovereign state. Newfoundland may have attained the status of a Dominion before 1931 . However, New foundland was explicitly given the status of a Dominion by the Statute of Westminster, 1931..$^{54}$

Section 2 of this Act provided that a law passed by a Dominion after the commencement of the Act would not be void by reason of its being repug. nant to the law of England. Section 3 provided that the Parliament of a Dominion had full power to make laws having extraterritorial operation. By s. 4 it was provided that no Act of the English Parliament passed after the commencement of the Act should extend to a Dominion without its consent.

Unfortunately, the Government of Newfoundland became unable to meet the interest charges on its public debt. The Legislative Council and the House of Assembly of New foundland delivered an address to Her Majesty which stated in part::55

Now, therefore. Your Majesty may be graciously pleased to suspend the Letters Patent under the Great Seal bearing the date at Westminster the Seventeenth day of July, 1905, and to issue new Letters Patent which would provide for the administration of the Island until such time as it may become self-supporting again, on the basis of the recommendations which are contained in the report of the Royal Commission and of which a summary is set out in the Annex hereto.

54. 22 Geo. 5, c.4.

55. The Newfoundland Act, 1944, 24 Geo. 5, c.2., First Schedule. 
The report of the Royal Commission recommended, in part, that: ${ }^{\text {se }}$

(c) The Commission of Government would be composed of six members, exclusive of the Governor, three of whom would be drawn from Newfoundland

(e) The proceedings of the Commission of Government would be subject to supervisory control by Your Majesty's Government in the United Kingdom, and the Governor-in-Commission would be responsible to the Secretary of State for Dominion Affairs in the United Kingdom for the good government of the Island

(g) It would be understood that, as soon as the Island's difficulties are overcome and the country is again self-supporting, responsible government, on request from the people of Newfoundland, would be restored.

In 1933 Britain acted on these recommendations and suspended the letters patent as requested. ${ }^{57}$

Government by Commission remained in effect in Newfoundland until 1949. Was Newfoundland a sovereign state during this period?

The Commission Government was directly responsible to the British Secretary of State for Dominion Affairs. Further, Great Britain negotiated a number of treaties which had effect within Newfoundland. Great Britain agreed by treaty that the U.S. should construct and operate air bases on the Avalon Peninsula and on the Southern coast of Newfoundland. ${ }^{68}$ Great Britain made an agreement by treaty with the U.S. regarding services at Gander Airport. ${ }^{59}$

Judicial authority is rather sparse on the question of what attributes a state must have if it is to be a sovereign state. It has been claimed that there are two English cases which lend support to the claims of Newfoundland. The first is Duff Development Co. Ltd. v. Government of Keltan ${ }^{60}$ The second is Mighell v. Sultan of Johore. ${ }^{61}$

In each of these cases a letter was addressed to the court at the direction of the Secretary of State. Each of the letters asserted that the state in question was considered by Great Britain to be a sovereign state. Both cases were decided on the rule of evidence that the statement of a proper government official as to the status which the government officially accords to another state is conclusive on the question of the status of that other state. Thus the value of these cases to Newfoundland is questionable.

Nevertheless, the cases do contain interesting obiter remarks. Relevant to our discussion is the following statement made by Viscount Finlay in Duff Development. ${ }^{62}$

It is obvious that for sovereignty there must be a certain amount of independence, but it is not in the least necessary that for sovereignty there should be complete independence. It is quite consistent with sovereignty that the sovereign may in certain respects be dependent upon another power; the control for instance, of foreign affairs may be completely in the hands of a protecting power, and there may be agreements or treaties which limit the powers of the sovereign even in internal affairs without entailing a loss of the position of a sovereign power.

56. Id, Annex to the First Schedule.

57. Section 1 of The Newfoundland Act authorized His Majesty to suspend the Letters $\mathrm{Pa}$ tent.

58. Leasing of Naval and Air Bases Between Great Britain and the United States, September 2, 1940, 12 Bevans 551, modified March 27, 1941, 12 Bevans 560.

59. Air Transport Services: Gander Airport, Newfoundland, Between Great Britain and the United States, May 23, 1947, 12 Bevans 814. This treaty amended an earlier treaty: Air Transport Services, Between Great Britain and the United States, February 11. 1946, 12 Bevans 726.

60. [1924] A.C. 979 (H.L.).

61. [1894] 1 Q.B. L49 (Eng.C.A.).

62. Duff Development Co. Ltd. v. Government of Keltan, supra n.60. 
In his text on international law Oppenheim says the following of a sovereign state. ${ }^{63}$

In consequence of its external independence a State can, unless restricted by treaty, manage its international affairs according to discretion; in particular it can enter into alliances and conclude other treaties, send and receive diplomatic envoys, acquire and cede territory, make war and peace.

In consequence of its internal independence and territorial supremacy, a State can adopt any constitution it likes, arrange its administration in any way it thinks fit, enact such laws as it pleases....

Commission Government was instituted at the request of Newfoundland and was removed at its request. It was always understood that the measure was temporary. Newfoundland remained as a distinct entity under a government which contained residents of Newfoundland but was responsible to Britain. The government of Newfoundland was never entirely merged with that of Great Britain. The fact that Newfoundland did not have complete control over its foreign affairs is not sufficient to preclude its having been a sovereign state. However, it appears that Newfoundland cannot bring itself within the requirement of Viscount Finlay that a sovereign state have some degree of independence. During the period of Commission Government Newfoundland was able to influence the decisions of Great Britain, but the island had no independence at all. Thus it would appear that even if the continental shelf doctrine was recognized in 1949, Newfoundland's claim fails because it was not a sovereign state at that time.

\section{CLAIM TWO}

Even if Newfoundland lost on its claim to the resources under the entire continental margin it might succeed with a less extensive claim. Newfoundland could claim that at the time of Union it was entitled at international law to exercise sovereignty within 3 miles of its shoreline and that it did so. Thus before Union this area would have been part of Newfoundland and the minerals in it would have belonged to Newfoundland. By the terms of Union this area and the minerals in it would continue to belong to Newfoundland today.

Canada might deny that Newfoundland was entitled before union to exercise sovereignty over this 3 mile strip. It might be claimed that sovereignty was first exercised over this 3 mile belt by Canada.

Newfoundland was brought into confederation by the British North America Act, 1949. ${ }^{.4}$ This Act gave the terms of Union of Newfoundland with Canada the force of law. ${ }^{65}$ The 2nd term of Union provided that:

The Province of New foundland shall comprise the same territory as at the date of Union, that is to say, the island of Newfoundland and the islands adjacent thereto, the Coast of Labrador as delimited in the report delivered by the Judicial Committee of His Majesty's Privy Council on the first day of March, 1927, and approved by His Majesty in His Privy Council on the twenty-second day of March, 1927, and the islands adjacent to the said Coast of Labrador.

The 7th term provided that:

The Constitution of Newfoundland as it existed immediately prior to the sixteenth day of February, 1934, is revived at the date of Union and shall, subject to these terms and the British North American Acts, 1867 to 1946, continue as the Constitution of the Province of Newfoundland from and after the date of Union, until altered under the authority of the said Acts.

63. L. Oppenheim, International Law: A Treatise, s. 124, (8th ed. 1955) 286.

64. 12 and 13 Geo. 6, c.22.

65. Id schedule. 
By the 37th term:

All lands, mines, minerals, and royalties belonging to New foundland at the date of union, and all sums then due or payable for such lands, mines, minerals, or royalties, shall belong to the Province of Newfoundland, subject to any trusts existing in respect thereof, and to any interest other than that of the province in the same.

A. The B.C. Offshore Minerals Reference

The leading case in the area of entitlement to resources within territorial waters is the $B . C$. Offshore Minerals Reference. ${ }^{66}$ In it, the Supreme Court discussed $R$ v. Keyn. ${ }^{67}$ The discussion of the Court can be paraphrased as follows:

In Keyn the foreign commander of a foreign ship was indicted for manslaughter after there was loss of life on a British ship which his ship struck while passing within three miles of the Port of Dover. The majority of the court in Keyn held that the territory of England ends at low-water mark and thus the British courts did not have jurisdiction. The Territorial Waters Jurisdiction Act (Eng.) (1878) ${ }^{88}$ was passed to bring offences committed within one marine league (approximately 3 statute miles) of the coast within the jurisdiction of the Admiral. The Supreme Court stated that this legislation did not enlarge the realm of England and that even after its enactment the majority opinion in Keyn that the territory of England ends at low-water mark was undisturbed ${ }^{69}$

To express its conclusion in the initial part of its judgment the court adopted the following statement: ${ }^{70}$

1. The realm of England where it abuts upon the open sea only extends to low water mark; all beyond is the high sea.

2. For the distance of three miles, and in some cases more, international law has conceded an extension of dominion over the seas washing the shores.

3. This concession is evidenced by treaty or by long usage.

4. In no case can the concession extend the realm of England so as to make the conceded portion liable to the common law, or to vest the soil of the bed in the Crown. This must be done by the act of the Legislature.

Later the Supreme Court said "We are not disputing the proposition that while British Columbia was a Crown Colony the British Crown might have conferred upon the Governor or Legislature of the colony rights to which the British Crown was entitled under international law but the historical record of the colony does not disclose any such action."71

Although British Columbia cited a number of precedents which it argued contradicted $R$. v. Keyn the Supreme Court either distinguished these or characterized them as dicta. ${ }^{72}$ The Supreme Court stated that "the rights in the territorial sea formerly asserted by the British Crown in respect of the Colony of British Columbia were after 1871 asserted by the British Crown in respect of the Dominion of Canada". ${ }^{73}$ The effect, the Supreme Court said, of the Territorial Waters Jurisdiction Act (Eng.) (1878) was that the United Kingdom claimed jurisdiction over a territorial

66. Supra n.1.

67. R. v. Keyn (1876), 2 Ex. D. 63 (Eng.).

68. 41-42 Vict., c. 73 (1878).

69. B.C. Offshore Minerals Reference, supra n.1 at 805.

70. Id at 807.

71. Id. at 808 .

72. Id. at 808-14.

73. Id at 815 . 
sea in respect of the Dominion of Canada. The Supreme Court stated that Canada became a sovereign state some time between 1919 and the Statute of Westminister, 1931 and thus became the state which is recognized by international law as having rights in the territorial sea adjacent to the Province of British Columbia. ${ }^{74}$ The court held that Canada has sovereignty over a territorial sea 3 miles wide. ${ }^{75}$

A similar problem was canvassed in the Tide-water cases in the United States Supreme Court. ${ }^{76}$ California, Texas and Louisiana were each unsuccessful in claiming against the Federal government entitlement to the territorial waters within 3 miles of their coasts.

A similar question was discussed in New South Wales v. Australia. ${ }^{77}$ Jacobs, J. said at 107:

Whether the boundaries of the colony be proclaimed by letters patent or delineated by statute, far from there being an implication that some part of the sea was intended to be included the implication must be to the contrary. However, it should be noted that the colony, like England, will include the waters intra fauces terrae and the seashore between high and low-water mark and the accretions thereto by slow and imperceptible change.

At 108 he stated:

Nor could there be any rule of law operating to bring within the boundaries of a colony, defined by letters patent or by statute or otherwise, a part of the seas which did not expressly or by implication fall within the boundaries so defined.

At 21 McTiernan J. quoted the following from Wheaton's Elements of International Law.

The maritime territory of a state extends to the ports, harbours, bays, mouths of rivers, and adjacent parts of the sea enclosed by headlands belonging to the same State. The general usage of nations super - adds to this extent of territorial jurisdiction a distance of a marine league ... along all the coasts of the state. Within these limits, its rights of property and territorial jurisdiction are absolute and exclude those of every other nation.

\section{B. Entitlement to Resources Under the Territorial Waters Surrounding} Newfoundland

The 1610 crown charter of Newfoundland granted the colony ownership of the "seas and islands lying within ten leagues of any part of the sea coast". ${ }^{78}$ The colony of Newfoundland enacted a fair amount of legislation concerning the territorial sea. A 1933 act authorized the boarding of vessels "hovering in territorial waters of Newfoundland". ${ }^{79}$ By description these waters included ${ }^{80}$

the waters adjacent to the Dominion, within 3 nautical miles thereof in the case of any vessel registered in Newfoundland.

A 1903 act provided for the granting of mining licenses for areas "covered by the sea or public tidal waters".81

It is unlikely that the Supreme Court would be persuaded by this

74. Id. at 816 .

75. Id.

76. United States v. California 332 U.S. 19 (1947)(U.S.S.C.); United States v. Louisiana 339 U.S. 699 (1950) (U.S.S.C.); United States v. Texas U.S. 707 (1950) (U.S.S.C.).

77. (1976) 8 A.L.R. 1.

78. J. Hazard, supra n.53 at 144.

79. Customs Act, 23 and 24 Geo. 5, c. 57, s. 131 (1933) (Nfld.).

80. Id. S. 1(p). See also s.9.

81. The Crown Lands Act, 3 Edu. 7, c.6, s.49(1) (Nfld.) (1903). 
evidence. For example, when considering the Conception Bay case ${ }^{82}$ the Court in the B.C. Offshore Mineral Reference said::33

The Imperial Legislature conferred upon the Legislature of New foundland the right to legislate with regard to Conception Bay as part of the territory of Newfoundland. This is the ratio of the case and it does not carry with it any general delegation by the British Crown over the territorial sea surrounding Newfoundland.

It would be open to the Court to hold that since the territorial waters surrounding Newfoundland were never expressly made a part of Newfoundland after it became a sovereign State, they were never within the territory of Newfoundland. The Court could then hold that the territorial waters have been within the territory of Canada since the enactment of the Territorial Sea and Fishing Zones Act (1964) (Can.). ${ }^{84}$

\section{CLAIM THREE}

The offshore oil industry in the vicinity of Newfoundland is still in a very early stage of development. A study of legislative competence to regulate this industry is therefore somewhat premature.

In the B.C. Offshore Minerals Reference the Supreme Court came to the following conclusions.$^{85}$ Canada has exclusive jurisdiction with regard to lands under the territorial sea either under s.91(1)(a) of the B.N.A. Act or under the residual power in S.91 of the B.N.A. Act. British Columbia has no legislative jurisdiction since the lands in question are outside its boundaries. The lands under the territorial sea do not fall within any of the enumerated heads of s.92 since they are not within the province. Legislative jurisdiction with respect to such lands therefore must belong exclusively to Canada since the subject matter is not one assigned exclusively to the provincial legislatures within the meaning of the initial words of s.91. Thus, the subject matter may be regarded as a matter affecting Canada generally and covered by the expression "the peace, order and good government of Canada". Further, the rights in the territorial sea depend upon recognition by other sovereign states; and Canada is a sovereign state recognized by international law and thus able to enter into arrangements with other states respecting the rights in the territorial sea.

The court stated that British Columbia also lacked legislative jurisdiction over the continental shelf for two reasons ${ }^{86}$ First, the shelf is under the high seas and accordingly outside the territory of British Columbia. Second, it is only Canada, a sovereign state, which will be recognized in this area by other sovereign states and to which other states will look for the fulfillment of international obligations such as the maintenance of safe shipping.

It is unlikely that Newfoundland would be any more successful than British Columbia in claiming legislative jurisdiction in this area.

82. The Direct United States Cable Company v. The Anglo-A merican Telegraph Company (1877), 2 App. Cas. 394, 46 L.J.P.C. 71.

83. B.C. Offshore Minerals Reference. supra n.1 at 809.

84. 1964-65, c.22, assented to 16 July 1964 .

85. B. C. Offshore Minerals Reference, supra n.1 at 816-7.

86. Id at 821 . 


\section{CONCLUSION}

Preparations have been made to take a reference on this matter to the Supreme Court of Canada. Prime Minister Clark will decide whether or not the reference which has been prepared will proceed. If the decision of the Prime Minister is consistent with speeches he has made, the reference will not go forward. On September 8th, 1978 Prime Minister Clark said, "I and five Progressive Conservative Premiers support changes which we believe would be welcomed by other Provinces as well. These include recognition of provincial ownership of offshore mineral resources." On March 3rd, 1979 the Prime Minister said, "We have resources that lie under the ground and under the water, resources that in my judgment are in the primary jurisdiction of the Provinces." 